Бранимир В. Станковић ${ }^{1}$

Универзитет у Нишу

Филозофски факултет

Департман за србистику

Лидија С. Тасић

Универзитет у Нишу

Педагошки факултет у Врању
УДК 81`1

Прегледни научни рад

Примљен: 16. мај 2021.

Прихваћен: 1. јун 2021.

DOI: https://doi.org/10.46630/gsrj.19.2021.21

\title{
„КУРС ОПШТЕ ЛИНГВИСТИКЕ” И КРИТИЧАРИ СОСИРОВИХ ИДЕЈА
}

Рад нуди приказ критичких осврта на идеје формулисане у Сосировом Курсу опште лингвистике. Пре свега, Јакобсонова фонолошка истраживања показала су да је Сосирова тврдња о очигледној линеарности језичког израза (с обзиром на чињеницу да два означитеља никада не могу бити реализована истовремено) у ствари petitio principii - не само да је могуће синхроно реализовати два или више фонолошких дистинктивних обележја, „већ је ово уобичајен феномен, будући да су фонеме саме по себи комплексни ентитети" (ЈАКОБСОН 1978: 99). Бенвенист (1966) сматра да веза између двеју компоненти језичког знака, означитеља и означеног, није арбитрарна, како је окарактерисао Сосир, већ је нужна. Коментар антрополога Леви-Строса (1973), настављача Јакобсонових идеја у оквиру структуралистичке теорије мита, гласи да је језички знак арбитраран a priori, али да је он за изворне говорнике мотивисан a posteriori. Коначно, занимљиво је неслагање Сосира и Чомског у погледу чувене дихотомије langue:parole и дефинисања предмета лингвистике. Према Сосиру (1916: 31), parole подразумева индивидуалне, слободне креиране комбинације у оквиру језичког кода помоћу којих говорник изражава сопствене мисли, али говор укључује и психолошке механизме који омогућавају екстериоризацију ових комбинација. Међутим, за Чомског (1964) рекурзивни процеси који стоје у позадини генерисања реченице никако не представљају фриволни акт сваког појединачног говорника, већ они подлежу строгим, систематским правилима, који чине langue, као кључни предмет проучавања синтаксе, тј. науке о језику уопште. Коначно, Чомски лоцира другачије место за лингвистику у систему научних дисциплина. Уместо чувене Сосирове семиологије, Чомски сматра да је лингвистика део другог епистемолошког система, те да припада корпусу когнитивних наука.

Кључне речи: Курс опште лингвистике, Фердинанд де Сосир, Роман Јакобсон, Емил Бенвенист, Ноам Чомски, језички знак, langue, parole, семиологија, когнитивне науке

\footnotetext{
${ }^{1}$ branimir.stankovic@filfak.ni.ac.rs

${ }^{2}$ Непубликован реферат под истим насловом представљен је на 12. Међународном научном скупу „Српски језик, књижевност, уметност”, који је 27-28. 10. 2017. године одржан на Филолошко-уметничком факултету у Крагујевцу, у оквиру сесије „Фердинанд де Сосир и утемељење модерне лингвистике: лингвистика пре и после Сосира”.
} 


\section{1. Увод}

Швајцарски лингвиста Фердинанд де Сосир (1857-1913) сматра се оцем модерне структуралистичке ${ }^{3}$ лингвистике, која је начинила значајан теоријско-методолошки заокрет од компаративно-историјског и младограматичарског програма, доминантних у европској науци о језику током 19. века. Међутим, чињенице које се тичу ове мале научне револуције више су него занимљиве. Наиме, целокупни Сосиров научни рад обележила је младограматичарска перспектива, а легендарни Cours de linguistique générale (Курс опште лингвистике) (СОСИР 2016), који он сам никада није у целини „ставио на папир” и публиковао ${ }^{4}$, постхумно је објављен на основу белешки са предавања неколицине његових женевских студената. Млади Фердинанд у 19. години одлази на студије индоевропеистике у Лајпциг, центар младограматичарског покрета, те као двадесетједногодишњак објављује Mémoire sur le système primitif des voyelles dans les langues indo-européennes (Дисертација о древном систему вокала у индоевропским језицима) (СОСИР 2009). Овај рад ће по први пут поставити хипотезу о претпостављеним, давно присутним сонантним коефицијентима (coefficients sonantiques) у протоиндоевропском, која ће (у нешто модификованом облику и под називом ларингална теорија) бити потврђена пола века касније открићем и дешифровањем хетитског језика. У „младограматичарском” Лајпцигу је 1880. године одбранио и докторску дисертацију на тему De l'emploi du génitif absolu en Sanscrit (О употреби апсолутног генитива у санскриту) (СОСИР 2014). Након тога је на Универзитету у Паризу предавао санскрит, готски и старовисоконемачки, да би се 1892. вратио у родну Женеву, где је све до смрти 1913. године подучавао санскрит и индоевропеистику на Универзитету у Женеви. Предавања опште лингвистике држао је само током три академске године, између 1907. и 1911., али ће његове иновативне идеје о природи људског језика, захваљујући ентузијазму и напорима ученика Шарла Баија (Charles Bally) и Албера Сешеа (Albert Sechehaye), ипак угледати светлост дана пет година касније. Ово ће дело заувек променити курс научног проучавања језика у правцу структурализма, методе које ће убрзо бити преузета и прилагођена истраживањима у науци о књижевности, антропологији, социологији, психологији, архитектури, па чак и економији (СТАНКОВИЋ 2020).

У овом раду представићемо критичке ставове тројице великана свет-

\footnotetext{
${ }^{3}$ Треба нагласити да Сосир никада није употребљавао термин структура у оном значењу (или, боље, не у значењима) које му се придаје од Прашког лингвистичког серкла наовамо.

${ }^{4}$ Било је више таквих покушаја, али читаве две или три деценије пре 1907-1911. године, када ће коначно добити прилику да своје идеје изнесе на предавањима Опште лингвистике на Универзитету у Женеви. Године 1996. у његовом женевском летњиковцу пронађене су и белешке за предавања, објављене 2002. као Ecrits de linguistique générale (Списи о општој лингвистици) (СОСИР 2006).
} 
ске науке о језику - Романа Јакобсона (Роман Якобсон), Емила Бенвениста (Émile Benveniste) и Ноама Чомског (Noam Chomsky) - о појединим идејама изнетим у Курсу опште лингвистике. Они се тичу неких од најважнијих концепата Сосировог модела: односа синхронијске и дијахронијске лингвистике, арбитрарне природе језичког знака, линеарности језичких израза, дистинкције између језика и говора, места језикознања у систему научних дисциплина. Показаћемо да се легатом једног научника не сматрају само хипотезе и теорије које буду позитивно верификоване, већ чак и оне идеје које се на крају испоставе нетачним, али које друге истраживаче покрећу на критичку надоградњу. Препознавање нових, релевантних проблема у феномену који се испитује може бити први корак оригиналног научноистраживачког рада.

Рад има следећу композицију. Други, трећи и четврти одељак посвећени су критичким освртима на Курс опште лингвистике Јакобсона, Бенвениста и Чомског, респективно. Пети одељак доноси закључак.

\section{2. Јакобсон о статичкој и еволутивној лингвистици и о линеарности означитеља}

Утицај Сосира на формирање лингвистичке мисли Романа Јакобсона (1896-1982) очигледан је још од првих његових радова, тачније, од 1921. године, када у Прагу излази из штампе први део дела Новейшая русская поэзия (Најновија руска поезија) (ЈАКОБСОН 1921), трактат посвећен поетском методу руског футуристе Хлебњикова. У њему Јакобсон заступа Сосирову идеју да само статичке методе истраживања омогућују да се живи језички процеси изолују од петрифицираних форми, односно, омогућују изоловање лингвистичког система од ,лингвистичке прашине”. Наиме, у трећем поглављу Курса, насловљеном Статичка и еволутивна лингвистика, швајцарски лингвиста ова два термина користи као синониме за синхронијску и дијахронијску лингвистику. Он сматра да су истраживање структурних односа у оквиру једног језика или између више језика у одређеном временском пресеку и истраживање о гласовним променама и њиховим односима током одређених временских периода одвојени и међусобно се искључују, те заговара поступак у коме се прво спроводи статичка анализа целокупности појединих етапа развоја, да би се тек потом истраживала еволутивна перспектива језика. У седмом одељку првог поглавља Курса Сосир чак експлицитно негира могућност заузимања панхронијске перспективе. Међутим, Јакобсоново постепено удаљавање од ове идеје почиње веома рано. Beћ 1928., у коауторском раду са Тињановим (Юрий Тынянов) Проблемы изучения литературы и языка (Проблеми изучавања књижевности и језика), он пише: 
„Чисти синхронизам се показао као обична илузија: сваки синхронијски систем има своју прошлост и будућност као неодвојив део система... Опозиција између синхроније и дијахроније губи на својој важности, у принципу, оног тренутка када препознамо да сваки систем неопходно постоји као еволуција, при чему, на другој страни, еволуција незаобилазно има систематску природу.” (ЈАКОБСОН 1928, према МАТЕЈКИ 1997)

Наредне, 1929. године Јакобсон износи мишљење да статичку и еволутивну перспективу не би требало поистовећивати са синхронијском и дијахронијском лингвистиком. Коначно, у Тезама Прашког лингвистичког серкла, програму представљеном на Првом конгресу филолога слависта у Прагу исте године, истиче се да би било неразумно подићи непремостиве баријере између синхронијског и дијахронијског метода, како то чини Женевска школа (ТЕЗЕ 1929, према МАТЕЈКИ 1997).

Један од основних принципа Сосировог Курса јесте и идеја о линеарности означитеља (caractère linéaire du signifiant, linearité du signifiant) (поред арбитрарности језичког знака, о којима - језичком знаку и арбитрарности - ће бити речи у наредном одељку рада). У основи овог концепта стоји идеја да два језичка означитеља не могу бити реализована истовремено (нпр. две фонеме, две морфеме, два реченична конституента итд.). Овакав се став, на први поглед, чини готово очигледним и сасвим логичним. Сосир сматра да је линеарност означитеља фундаментална особина, „са несагледивим последицама" (СОСИР 1916: 70). Међутим, Јакобсон је показао да су наизглед елементарне честице језика, фонеме ${ }^{5}$, даље дељиве на фонолошка дистинктивна обележја, која се реализују истовремено приликом артикулације одговарајућег фона. Зато је Сосирова тврдња о линеарности језичког израза, по Јакобсону, petitio principii - не само да је могуће синхроно реализовати два или више фонолошких дистинктивних обележја, „већ је ово уобичајен феномен, будући да су фонеме саме по себи комплексни ентитети" (ЈАКОБСОН 1978: 99).

На крају овог одељка ћемо поменути још два пара Сосирових термина које је Јакобсон заменио својим. Пре свега, то су појмови асоцијативних (relations associatives) и синтагматских односа (relations syntagmatiques). Смештајући их у одговарајући координатни систем, Јакобсон асоцијативне односе in absentia објашњава на тзв. оси селекције, а синтагматске односе међу језичким знаковима in praesentia на ономе што он назива осом комбинације. С друге стране, фундаменталне термине Сосирове опште лингвистике langue и parole Јакобсон ће заменити кодом и информацијом, појмовима из кибернетике и теорије информације, дисциплинама које доживљавају процват половином 20. века, управо у време највеће продуктивности легендарног пражанина.

\footnotetext{
${ }^{5}$ Овде термин фонема (фра. phonème) користимо у Јакобсоновој, фонолошкој терминологији. За Сосира је phonème јединица фонетике (тачније, дисциплине која данас носи тај назив), а за коју Јакобсон употребљава термин фон/глас (фра. son).
} 


\section{3. Бенвенист и арбитрарност везе означитеља и означеног}

Идеја о језичком знаку, коју данас налазимо у готово свим уџбеницима опште лингвистике, потиче од Сосира. „Језички знак уједињује, не ствар и њено име, већ концепт и акустичку слику. Потоње не представља материјални звук, чисто физичку ствар, већ психолошки отисак звука, утисак који он чини на наша чула" (СОСИР 1916: 66). Он предлаже да се за целину, тачније, спој задржи термин (језички) знак, а да се термини конщепт и акустичка слика замене прецизнијим појмовима означено (signifiant) и означитељь (signifié). Потом одређује први принцип језичког знака - по својој природи, језички знак је арбитраран (l'arbitraire du signe). Тако, концепт сестра није везан никаквом скривеном везом са гласовима $s-o ̈-r$, који служе као њен означитељ у француском, и могли би потенцијално бити замењени било којим другим (фонолошки прихватљивим) низом гласова француског језика. Ово је једноставно доказиво чињеницом да се исти појмови исказују речима које се разликују од језика до језика, те самим фактом да уопште постоје различити језици.

Сосир предупређује и могуће приговоре на ову тврдњу, јер се чини да би се као изузетак од горепоменутог могле издвојити ономатопејске речи и узвици. Тако, он помиње аутентичне ономатопеје, под којима подразумева фигуре које се у реторици и теорији књижевности називају просте и сложене ономатопеје. Неаутентичне ономатопеје (иако Сосир не користи овај термин), пак, биле би речи које имају одређену фоносимболику (још једном, Сосир их конкретно не описује на овај начин). Међутим, обема групама се мотивисаност између означитеља и означеног не може приписати јер нам еволутивна перспектива ових речи открива како оне константно мењају своју форму, што значи да се у различитим епохама различитим означитељима означавају исти концепти. С друге стране, иако на први поглед делује као да „Узвици представљају спонтане изразе реалности које диктирају, да тако кажемо, природне снаге" (СОСИР 1916: 69), поређењем узвика са истом експресивном функцијом у двама различитим језицима (нпр. фра. aïe! и енгл. ouch!) лако можемо увидети да ово једноставно не стоји, тј. да не можемо утврдити никакву природну мотивисаност између означитеља и означеног ни за ову категорију речи.

Емил Бенвенист (1902-1976), један он најзначајнијих индоевропеиста структуралиста 20. века, критички се осврнуо на принцип немотивисаности језичког знака у својој монографији Problèmes de linguistique générale (Проблеми опште лингвистике). „Очигледно аргумент не стоји због несвесног, скривеног реферисања на трећи феномен, који није био укључен у почетну дефиницију." (БЕНВЕНИСТ 1966: 44). Под трећим појмом Бенвенист подразумева сам ентитет, „реалност” - могло би се рећи, трећи угао троугла референције Чарлса Огдена (Charles Ogden) и Ајвора Ричардса (Ivor Richards) (ОГДЕН-РИЧАРДС 1923). 
„Иако је Сосир рекао да концепт 'сестра' није повезан са означитељем $s-\ddot{o}-r$, он није узео у обзир реалност овог појма. Када је говорио о разлици између $b-\ddot{o}-f$ и $o-k-s$ ['во' у француском и енглеском, прим. аут.], упркос сопственом ставу, он износи и чињеницу да се ова два термина примењују за упућивање на исту реалност. Овде се, дакле, сама ствар, експресно искључена из дефиниције знака, увлачи заобилазним путем и заувек успоставља контрадикцију.” (БЕНВЕНИСТ 1966: 44).

Бенвенист подсећа да је Сосир заступао идеју да је језик форма, а не супстанца, те да је лингвистика искључиво наука о формама. Ово подразумева да је „супстанца”, била то сестра или во из његових примера, изван домена знака. Само у случају да се мисли на вола у његовој конкретној и „супстанцијалној” посебности, оправдано је сматрати ,арбитрарном” везу између $b-\ddot{o}-f$, на једној страни, и $o-k-s$, на другој, са истом реалношћу. Постоји, дакле, контрадикција између начина на који је Сосир дефинисао језички знак и темељне природе који му је приписао.

„Одлучити да је језички знак произвољан јер се иста животиња назива bøuf у једној земљи, а ox у другој је исто као да се тврди да је ожалошћеност арбитрарна јер се у Европи она симболизује црном бојом, а у Кини белом. Арбитрарно, да, али само под непристрасним погледом Сиријуса или за особу која се ограничила да посматра ствари изван везе успостављене између објективне реалности и људског понашања, осуђен да све време у тој вези види ништа друго до случајност”. (БЕНВЕНИСТ 1966: 44).

Бенвенист закључује да веза између означитеља и означеног није арбитрарна (немотивисана), већ да је ова веза нужна. У уму сваког говорника веза између концепта и акустичке слике је толико јака, да једно просто изазива друго, јер га подразумева. У том смислу, веза концепта и акустичке слике у језичком знаку је нужна, а арбитрарном би се могла сматрати веза између комплексног језичког знака и екстралингвистичког објекта на који реферише.

Овоме, коначно, треба додати и став антрополога Клода Леви-Строса (Claude Lévi-Strauss) (1908-2009), познатог настављача Јакобсонових идеја у оквиру структуралистичке теорије мита. Он сматра да је језички знак арбитраран a priori, али да је он за изворне говорнике заиста мотивисан $a$ posteriori. Након што је знак настао, те постао делом историје, он не може бити арбитрарно промењен (ЛЕВИ-СТРОС 1973: 91).

\section{4. Чомски о односу langue и parole и месту лингвистике у систему научних дисциплина}

Једна од најпознатијих Сосирових дихотомија представља однос између langue и parole, тј. језика и говора, како се стандардно ови појмови 
преводе. Према Сосиру, parole подразумева две компоненте. Са једне стране, под говором се подразумевају индивидуалне, слободно креиране комбинације у оквиру језичког кода помоћу којих говорник изражава сопствене мисли. Са друге стране, говор укључује и психолошке механизме који омогућавају екстериоризацију ових комбинација (СОСИР 1916: 31). Имајући у виду ово, Сосир реченицу, као предмет изучавања синтаксе, сврстава у говор, а не у језик, истичући да је она производ слободног избора говорника (СОСИР 1916: 172).

Овакво схватање у складу је са класичним структуралистичким концептом о растућој слободи у структури „одоздо нагоре”. На најнижем, фонолошком нивоу, избор јединица је сужен на мали број фонема и директно зависи од фонолошких и прозодијских ограничења. Избор се драстично повећава на нивоу деривационе и флективне морфологије, да би на нивоу синтаксе био максималан.

У лингвистици је уобичајено поређење Сосирових појмова languе и parole са концептима linguistic competence (језичка способност) и linguistic performance (језичка делатност) Ноама Чомског. Међутим, овакве су паралеле неприхватљиве имајући у виду начин на који Чомски интерпретира дате парове појмова. У раним радовима знаменитог америчког лингвисте, филозофа и активисте, у којима се бави ових феноменима, очигледно је само слагање у погледу редоследа појава (ЧОМСКИ 1963, ЧОМСКИ 1964). Сосиров languе претходи parole-у, онако како linguistic competence претходи linguistic performance-у. Међутим, Чомски не прихвата концепт langue-a јер га сагледава као пуко „складиште знакова (нпр. речи, фиксираних израза), њихових граматичких обележја, те, евентуално, одређених 'типова фраза"” (ЧОМСКИ 1963: 328). За њега је поменуто Сосирово тумачење природе реченице, тачније, механизама на којима се заснивају синтагматски односи језичких знакова, потпуно неприхватљиво.

„Био је [Сосир] прилично немоћан да разуме рекурзивне процесе који стоје у позадини деривације реченице, па се чини да изградњу реченице види као говор, а не језик у ужем смислу, као слободну и вољну креацију пре него као систематско правило. У његовој схеми нема места за 'правилима ограничену/ вођену креативност' какву налазимо приликом свакодневне употребе језика.” (ЧОМСКИ 1964: 23)

За Чомског рекурзивни процеси приликом генерисања реченице не представљају фриволни акт говорника, већ они подлежи строгим, систематским правилима, који представљају језичку способност, као кључни предмет проучавања синтаксе, тј. науке о језику уопште.

Ово, на крају, покреће и питање самог места које језикознање заузима у систему научних дисциплина. У трећем поглављу Курса, посвећеном предмету истраживања лингвистике, Сосир расправља о чињеници да је језик друштвена институција, која се, ипак, знатно разликује од осталих блиских 
феномена - политичких, правних институција и сл. - будући да се ради о систему знакова којима се изражавају идеје, па је у том смислу он пре упоредив са системом писања, знаковним језиком, симболичким ритуалима, формулама учтивости, војним сигналима и сл. Стога он предлаже конституисање дисциплине коју назива семиологија ${ }^{6}$ (sémiologie), која би се бавила „животом знакова у друштву (...) оним што чини знакове, законима који њима управљају" (СОСИР 1916: 16). Она би представљала део социјалне психологије, те, на послетку, и опште психологије. Лингвистика би тако била једна од поддисциплина семиологије, поред теорије војних сигнала, система писања итд. (в. графикон 1). Семиологија је потом, даљим развојем њене научне мисли, као саставни део наддисциплине семиотике постала теоријско жариште опште и социјалне антропологије у другој половини 20. века.

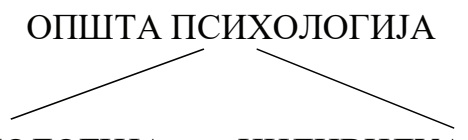

СОЦИЈАЛНА ПСИХОЛОГИЈА ИНДИВИДУАЛНА ПСИХОЛОГИЈА

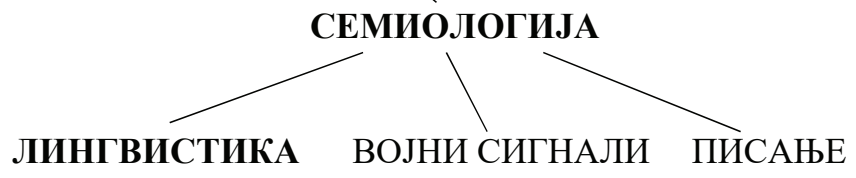

Графикон 1. Место лингвистике и семиологије у систему научних дисциплина према Сосиру

Чомски, међутим, лоцира другачије место за лингвистику у систему научних дисциплина. Године 1957. излази из штампе књига Verbal behavior (вербално понашање) психолога Баруса Фредерика Скинера (Burrhus Frederic Skinner), у којој се језик анализира у духу владајуће бихевиористичке психолошке парадигме да је предмет истраживања само понашање, без успостављања веза са хипотетичким менталним структурама, већ са околином у којој се понашање јавља као реакција. Чомски је две године касније објавио веома оштру критику овог модела, називајући покушај да се људски језик интерпретира бихевиористички пуком игром речи, која није заснована ни на каквим конкретно спроведеним експериментима (ЧОМСКИ 1959).

\footnotetext{
6 „За разлику од Сосира, амерички мислилац Чарлс Перс (Charles Pierce) почев од 1867. године развија идеју о семиотици, која је концептуално шира и обухвата семиологију. Наиме, у Персовој филозофији, уместо дијадног, постоји тријадни однос између знака (који одговара Сосировом означитељу), објекта и интерпретанта (interpretant). За разлику од Сосировог означеника, који је апстраховани концепт у уму говорника, Персов објекат представља конкретне ентитете. Трећи елеменат тријаде, интерпретант, представља однос људске свести према објекту, односно, разумевање односа између знака и објекта.” (СТАНКОВИЋ 2020: 13).
} 
Инсистирајући на изузетној продуктивности људског језика, Чомски објашњава да условне реакције не могу никако објаснити невероватну способност детета да разуме и произведе бесконачан број реченица прихватљивих говорној интуицији свих изворних говорника. Овај се критички приказ сматра кључним за преокрет од емпиризма ка ментализму у психологији, који се често третира као когнитивна револуција не само у психологији, већ и у другим хуманистичким наукама. Према томе, уместо Сосирове семиологије, Чомски сматра да је наука о језику део другог епистемолошког система - лингвистика припада ширем корпусу тзв. когнитивних наука ${ }^{78}$.

\section{5. Закључак}

У овом раду позабавили смо се појединим теоријско-методолошким иновацијама Сосирове лингвистике и различитим критичким реакцијама на његове идеје. Преиспитали смо фундаменталне дихотомије његове филозофије језика - статичку и еволутивну лингвистику, signifiant и signifié, langue и parole, арбитрарност и линеарност језичког знака. Поредили смо предмет језичкознања као део корпуса семиолошких/семиотичких знања и когнитивних наука.

Међутим, на општијем плану, покренули смо питање - шта то има потенцијала да иницира промене у владајућој научној парадигми? Случај Сосировог Курса опште лингвистике показује нам да чак и нетачне научне хипотезе, иако можда одбачене у потоњем развоју научне мисли, могу покренути низ нових истраживања и потпуно променити курс и фокус научне пажње на нови, до тада неразматрани, скуп феномена. Тако, посредно, неверификоване теорије рађају нове, веродостојне утврђеним емпиријским чињеницама.

Показали смо да се величина једног научника не огледа само у броју изнетих хипотеза и теорија, које бивају позитивно верификоване, већ чак и у оним идејама које се на крају испоставе као нетачне, али које умеју да покрену на рад друге истраживаче. Препознавање нових, релевантних проблема у феномену који се испитује може бити први корак оригиналног научноистраживачког рада.

\footnotetext{
${ }^{7}$ Притом је сам термин когнитивна наука (cognitive science) сковао Кристофер Лонгет-Хигинс (Christopher Longuet-Higgins) 1973. године у прегледном раду који се бавио проблемом вештачке интелигенције (ЛОНГЕТ-ХИГИНС 1973).

${ }^{8}$ Филозофи ума могу се класификовати у две групе у погледу класичне методолошке дебате о онтологији природних и хуманистичких наука. Према методолошким дуалистима, ментални феномени не могу се проучавати према једнаким стандардима рационалности који важе и за природне феномене. Као методолошки натуралист, Чомски је уједно и методолошки монист, који се залаже за једнаке стандарде у обема групама дисциплина (ЏЕЈКОБ 2002: 1).
} 


\section{Литература}

БЕНВЕНИСТ 1966: Émile Benveniste, Problèmes de linguistique générale, Paris: Gallimard, coll. (Bibliothèque des sciences humaines), 1-357.

ЈАКОБСОН 1921: Роман Якобсон, Новейшая русская поэзия, Набросок первый: подступь к Хлебникову, Prag: Politika, 1-68.

ЈАКОБСОН И ТИњАНОВ 1928: Роман Якобсон, Юрий Тынянов, Проблемы изучения литературы и языка, у: Тынянов Ю.Н. Поэтика. История литературы. Кино. - М., 1977. - С. 282-283.

JАКОБСОН 1978: Roman Jakobson. Six Lectures on Sound and Meaning. Hassocks: Harvester Press.

ЛЕВИ-СТРОС 1973: Claude Lévi-Strauss, Anthropologie Structurale Deux, Paris: Plon. $1-450$.

ЛОНГЕТ-ХИГИНС 1973: Christopher Longuet-Higgins, "Comments on the Lighthill Report and the Sutherland Reply". Artificial Intelligence: a paper symposium. Science Research Council, 35-37.

MATEJKA 1997: Ladislav Matejka, Jakobson's Response to Saussure's Cours, Cahiers de l'ILSL, N 9, 169-176.

ОГДЕН И РИЧАРДС 1923: Charles Kay Ogden, Ivor Armstrong Richards, The Meaning of Meaning: A Study of the Influence of Language upon Thought and of the Science of Symbolism, London: Kegan Paul, Trench, Trubner \& Co. Ltd., New York: Harcourt, Brace \& Company, Inc., 1-410.

СОСИР 1916: Ferdinand de Saussure, Cours de linguistique générale, Paris: Payot, $1-331$.

СОСИР 2006: Ferdinand de Saussure, Writings in General Linguistics (ориг. Ecrits de linguistique générale), Oxford: Oxford University Press, 1-366.

СОСИР 2009: Ferdinand de Saussure, Mémoire sur le système primitif des voyelles dans les langues indo-européennes, Cambridge: Cambridge University Press, $1-326$.

СОСИР 2014: Ferdinand de Saussure, De l'emploi du génitif absolu en Sanskrit, Cambridge: Cambridge University Press, 1-97.

СТАНКОВИЋ 2020: Бранимир Станковић, Основи прагматике, Ниш: Филозофски факултет, 1-203.

TE3E 1929: „Teze předložené 1. sjezdu slovanských filologů v Praze 1929”. 1. sjezd slovanských filologů v Praze, sekce II, These k diskusi, Prague: Sjezdový výbor, 1929.

ЧОМСКИ 1959: Noam Chomsky, „Reviews: Verbal behavior by В. F. Skinner”. Language 35/1: 26-58.

ЧОМСКИ 1963: Noam Chomsky, "Formal properties of grammars.", y: R. D. Luce, R. R. Bush и E. Galanter (ур.) Handbook of Mathematical Psychology, vol. 2. New York, London: John Wiley and Sons, 323-418. 
ЧОМСКИ 1964: Noam Chomsky, „Current issues in linguistic theory.” y: J. A. Fodor и J. J. Katz (ур.) The Structure of Language: Readings in the Philosophy of Language. Englewood Cliffs, NJ: Prentice-Hall, 50-118.

ЏЕЈКОБ 2002: Jacob, Pierre Chomsky, "Cognitive Science, Naturalism and Internalism”, HAL archives-ouvertes (https://jeannicod.ccsd.cnrs.fr/ijn_00000027)

Branimir Stanković, Lidija Tasić

\section{COURS DE LINGUISTIQUE GÉNÉRALE AND CRITICS OF SAUSSURE'S IDEAS}

The paper provides an overview of several important critical stances on Saussure's Cours de linguistique générale (1916). Jakobson's phonological analyses demonstrated that Saussure's idea about the apparent linearity of the language expression (given the fact that two signifiers cannot be produced simultaneously) is, in fact, petitio pricipii - not only is it possible to produce two or more distinctive features at the same time, "but this is common phenomenon as phonemes are complex entities" (JACOBSON 1978: 99). Benveniste (1966) deems that the connection between the two components of the language sign, the signified and the signifier, is not arbitrary, as characterized by Saussure, but necessary. Anthropologist Lévi-Strauss, Jakobson's devotee in the field of the structuralist theory of the mythos, commented that, for its users, the language sign is arbitrary a priori, but that it is motivated a posteriori. At last, there's an interesting dispute between Saussure and Chomsky on the famous langue:parole dichotomy and on defining the subject of linguistics itself. As for Saussure (1916: 31), parole stands for the individual, freely created combinations framed by the language code, used by the speakers to express their thoughts, but speech also includes the psychological mechanisms that enable the exteriorization of these combinations. But, Chomsky (1964) cannot simply interpret the recursive processes that are in the background of generating a sentence as a frivolous act of each individual speaker - in his theory, they are subject of severe, systematic rules, which should constitute langue, and which is the essential subject of interest of syntax, i.e. of linguistics, generally. Finally, Chomsky locates a different position for linguistics in the system of scientific fields. Instead of Saussure's renowned semiology, Chomsky regards linguistics as part of another epistemological system - as a discipline in the field of cognitive sciences.

Keywords: Cours de linguistique générale, Ferdinand de Saussure, Roman Jakobson, Émile Benveniste, Noam Chomsky, language sign, langue, parole, semiology, cognitive sciences. 